\title{
Rare case of sacral mass due to chondromyxoid fibroma
}

\author{
Ismail Turkmen, ${ }^{1}$ Burak Ozturan, ${ }^{2}$ Tuncay Kaner, ${ }^{3}$ Korhan Ozkan ${ }^{2}$
}

${ }^{1}$ Department of Orthopaedics and Traumatology, Beykoz State Hospital, Istanbul, Turkey ${ }^{2}$ Department of Orthopaedics and Traumatology, İstanbul Medeniyet University, Istanbul, Turkey

${ }^{3}$ Department of Neurosurgery, Istanbul Medeniyet University, Istanbul, Turkey

\section{Correspondence to}

Dr Ismail, Turkmen,

dr.ismailturkmen@gmail.com

Accepted 24 February 2016

\section{DESCRIPTION}

Chondromyxoid fibroma is a rare benign tumour derived from cartilage and generally seen in the metaphyseal region of long bones. It is rarely seen

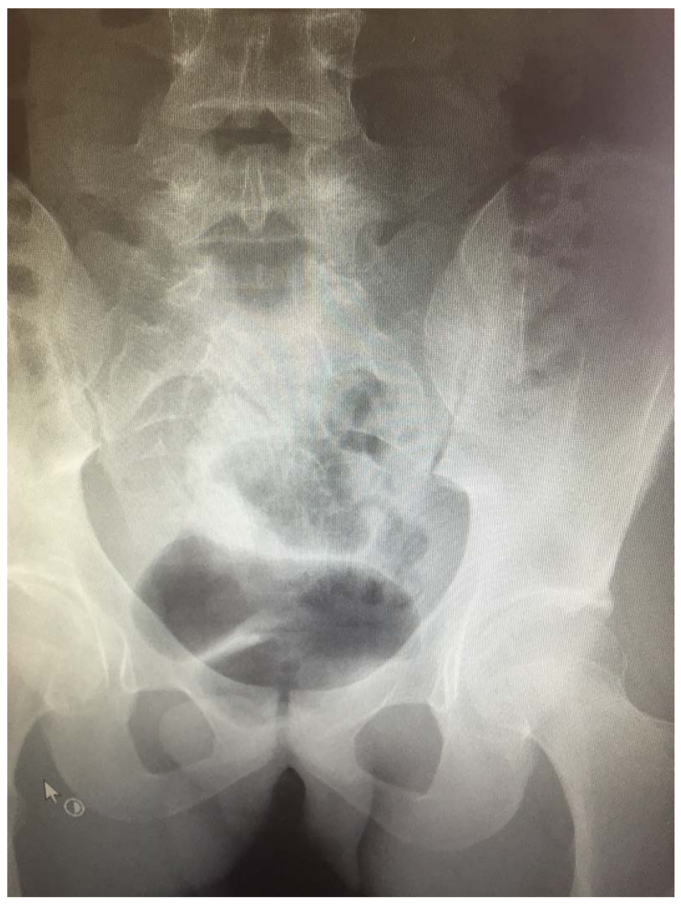

Figure 1 Anteroposterior roentgenography of the sacrum.

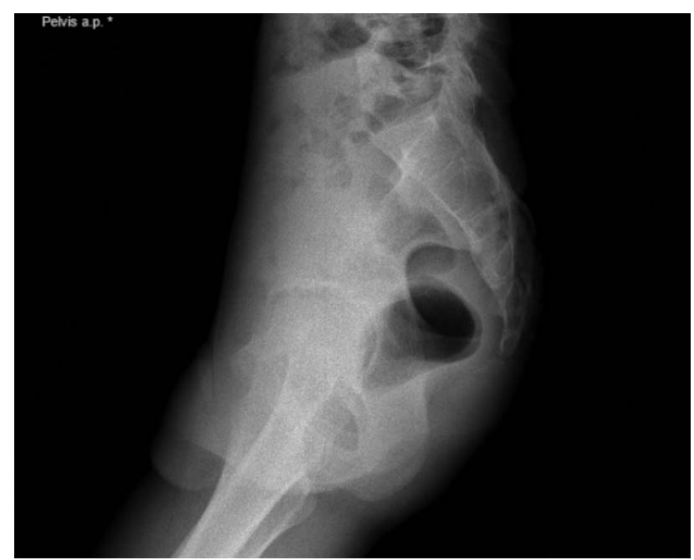

Figure 2 Lateral roentgenography of the sacrum.

in the axial skeleton. ${ }^{1-3}$ Fibroma, aneurysmal bone cyst, chondroblastoma and fibrous dysplasia must be evaluated in the radiographic differential diagnosis of chondromyxoid fibroma. Being an eccentric metaphyseal location, showing sharp, sclerotic, scalloped margins and matrix calcification are its major radiographic features. In pathological evaluation, the tumour shows a distinctly lobulated pattern of growth, with peripheral hypercellularity of the lobules, and the tumour cells are spindled and stellate. The stroma is myxoid, but rarely wellformed hyaline cartilage is present.

An 18-year-old male patient was admitted to our clinic with increasing coccydynia for 6 months.
To cite: Turkmen I, Ozturan B, Kaner T, et al. BMJ Case Rep Published online: [please include Day Month Year] doi:10.1136/ bcr-2015-214145

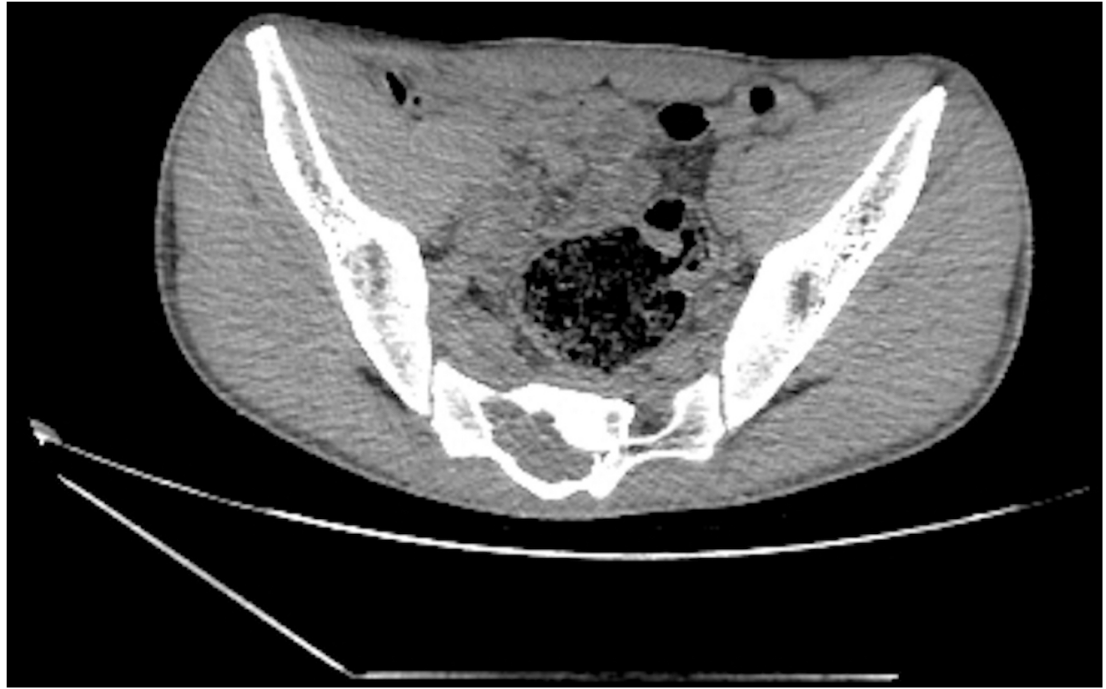

Figure 3 Axial CT view of the sacrum. 


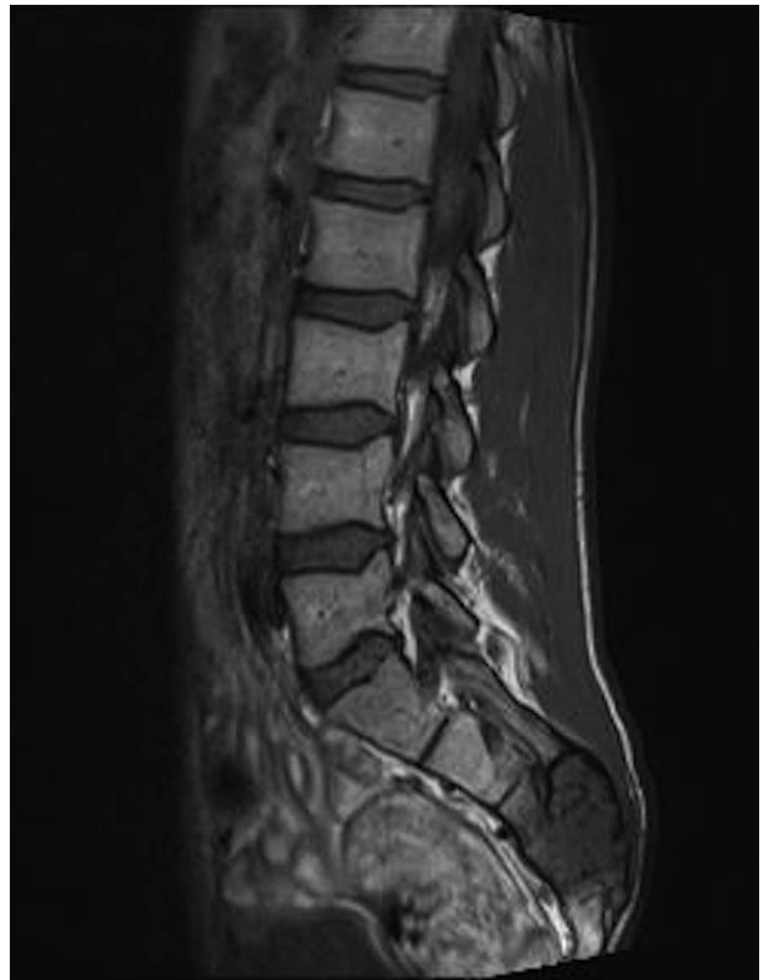

Direct roentgenography revealed a sacral mass (figures 1 and 2). CT and MRI demonstrated an osteolytic expansile soft tissue mass on sacral (S 2-3) vertebrae (figures 3 and 4). A suspected chondromyxoid fibroma was reported on needle biopsy. Intralesional curettage and hydroxyapatite grafting was performed. The pathology report confirmed the definitive diagnosis to be chondromyxoid fibroma (figure 5). No recurrence was seen in 1-year follow-up and no pain was detected. This case demonstrates a differential diagnosis for back pain due to sacral mass in young adults.

\section{Learning points}

- Coccygeal and sacral pain should be evaluated for possible tumoural masses as well as trauma, fractures, infections and sacroiliac joint pathologies.

- Ultrasonography, direct roentgenography, CT and MRI may be used for diagnosis. Biopsy should be performed in the first step to detect the possible pathology and plan the final treatment approach in cases of a tumoural mass.

- Chondromyxoid fibroma may affect the sacrum as it does in the long bones and should be included in the differential diagnoses of sacral lesions in young adults. A biopsy is mandatory for definitive diagnosis.

Figure 4 Sagittal MRI of the sacrum.

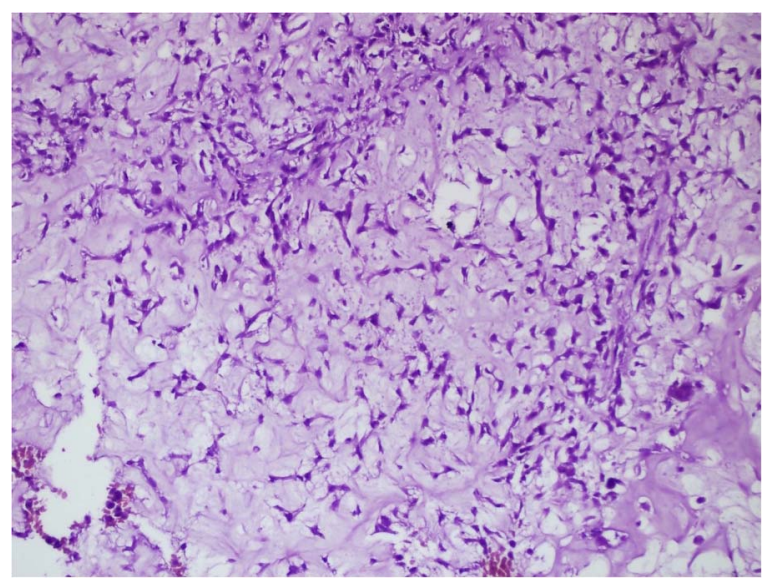

Twitter Follow Ismail Turkmen at @sporhekimi

Competing interests None declared.

Patient consent Obtained.

Provenance and peer review Not commissioned; externally peer reviewed.

\section{REFERENCES}

1 Rodgers WB, Kennedy JG, Zimbler S. Chondromyxoid fibroma of the ala of the sacrum presenting as a cause of lumbar pain in an adolescent. Eur Spine $J$ 1997;6:351-3.

2 Brat HG, Renton P, Sandison A, et al. Chondromyxoid fibroma of the sacrum. Eur Radiol 1999;9:1800-3.

3 Ahuja SK, McCanna SP, Horn EM. Treatment strategy for chondromyxoid fibroma of the sacrum. J Clin Neurosci 2011;18:1550-2.

Figure 5 Microscopic view of the tumour. At high magnification, the central portion of the tumour is chondromyxoid (H\&E stain, $\times 200)$.

Copyright 2016 BMJ Publishing Group. All rights reserved. For permission to reuse any of this content visit http://group.bmi.com/group/rights-licensing/permissions.

BMJ Case Report Fellows may re-use this article for personal use and teaching without any further permission.

Become a Fellow of BMJ Case Reports today and you can:

- Submit as many cases as you like

- Enjoy fast sympathetic peer review and rapid publication of accepted articles

- Access all the published articles

- Re-use any of the published material for personal use and teaching without further permission

For information on Institutional Fellowships contact consortiasales@bmjgroup.com

Visit casereports.bmj.com for more articles like this and to become a Fellow 